Journal of Islamic Medicine

Volume 2 (4) (2018), Pages 26-32

\title{
FRUCTOSE ALTERS THE EXPRESSION OF TYPE B LEPTIN RECEPTOR IN HYPHOTALAMUS AND INTESTINUM OF Rattus Novergicus
}

\author{
Ermin Rachmawati ${ }^{1}$, Risma Aprinda Kristanti ${ }^{1}$, Nurlaili Susanti ${ }^{2}$ \\ ${ }^{1}$ Physiology Laboratory, School Of Medicine Faculty Of Medicine And Health Science, Universitas \\ Islam Negeri Maulana Malik Ibrahim Malang Indonesia \\ ${ }^{2}$ Pharmacology Laboratory, School Of Medicine Faculty Of Medicine And Health Science, Universitas \\ Islam Negeri Maulana Malik Ibrahim Malang Indonesia
}

Background: Several epidemiological data's reported significant correlation between fructose consumption and diabetes mellitus type 2 by inducing insulin resistance. Leptin resistance induced by fructose was proposed as one novel mechanism that induce insulin resistance but the exact mechanism remains unclear. We hypothesize that fructose diminish the type b leptin receptors in hypothalamus and intestine.

Aim: This study was aimed to elucidate fructose effect on the expression of leptin receptor type b in hypothalamus and intestine of Rattus novergicus.

Method: twenty eight rats were used and divided into 4 groups: Group 1 was control, group 2 was given fructose $10 \%$, group 3 was given fructose $30 \%$ and group 4 was given fructose $55 \%$ for 2 months. At the end of treatment, the animal were sacrificed and then the hypothalamus and intestine were collected. The expression of type b leptin receptor were measured by immunohistochemistry technique with primary antibody from Bioss antibodies type Leptin receptor polyclonal antibody bs-0109R using Staining kit Skytec Laboratories and DAB chromogen. A positive expression can be seen as a brown colour in cell cytoplasm and counted in 100 cell. The expression then analysed using SPSS 18 with anova one way tes $(\mathrm{p}<0,05)$ followed by post hoc test after the data showed normality and homogeneity using Saphiro wilk and Levene test $(\mathrm{p}>0,05)$.

Result: There was significant differences in type b leptin receptors found in hypothalamus between each group $(\mathrm{p}<0.05)$. The significant differences also could be seen in the expression between control and group fructose 30 and $50 \%$ in intestinal cell $(\mathrm{p}<0.05)$.

Conclusion: the consumption of Fructose 55\% for 2 months attenuates the expression of type b leptin receptors in hypothalamus and intestine of Rat novergicus.

Contact person : Ermin Rachmawati

HP : +6281331478568 


\section{Pendahuluan}

Globalisasi, urbanisasi, kemajuan dunia teknologi menyebabkan peralihan pola konsumsi populasi penduduk manusia menjadi tinggi kalori, dimana sumber energi tersebut salah satunya didapat dari gula dan pemanis buatan. Konsumsi gula menunjukkan tren meningkat di seluruh dunia termasuk negara berkembang utamanya Asia dan India. Amanda dalam penelitiannya melaporkan bahwa di Brazil terjadi peningkatan konsumsi gula dari sumber nasi, tepung, kopi, jus buah dan minuman ringan (Souza AM, 2013). Hasil serupa dari sebuah data survey nasional di Amerika Serikat menunjukkan adanya peningkatan asupan energi dari makanan minuman berkalori tinggi dengan pemanis sebesar 3,9 kalori pada tahun 1977 menjadi 9,2\% di tahun 2001 (Nielsen SJ, 2004). Hasil studi lain menyebutkan bahwa prevalensi konsumsi minuman ringan di antara pemuda usia 6 hingga 17 tahun meningkat 48\%, dari 37\% di 1977/1978 menjadi 56\% di 1994/1998(French SA, 2003). Produk High Fructose Corn Syrup (HFCS) sebagai inovasi perkembangan teknologi industri makanan yang merupakan pemanis buatan utama pada makanan maupun minuman kemasan dikarenakan harga murah dan rasa yang manis (Walker RW, 2014). Berdasarkan data survei nasional di Amerika Serikat, konsumsi fruktosa yang didapat dari dua sumber utama yaitu sukrosa dan HFCS meningkat sebesar 26\% dari 64 gram/hari ditahun 1970 menjadi 81 gram/hari di tahun 1997 (Puttnam JJ, 1999).

Beberapa penelitian berhasil membuktikan hubungan antara konsumsi fruktosa dengan peningkatan insidens obesitas melalui stimulasi lipogenesis hepatik dan glukogenesis yang menjadi dasar terjadinya penyakit metabolik salah satunya adalah DM tipe 2 (Malik, 2010; Elliot SS, 2002). Publikasi dari hasil penelitian yang dilakukan oleh Fatma Akar menunjukkan bahwa diet tinggi fruktosa menyebabkan terjadinya stress oksidatif sebagai pemicu resistensi insulin(Akar F, 2012, Martinez MJ, 1994, Bezzera RMN et al, 2001).

Selain resistensi insulin yang disebabkan kondisi hiperlipidemia dan hiperglikemia, sebuah mekanisme novel resistensi leptin berkembang sebagai salah satu patofisiologi DM tipe 2. Masih terdapat perdebatan mengenai berapa lama paparan fruktosa yang menyebabkan resistensi leptin. Shapiro dalam penelitiannya menyebutkan bahwa tikus menjadi resisten leptin setelah diberi perlakuan tinggi fruktosa selama 6 bulan (Shapiro A et al, 2008). Samantha menyanggah hasil penelitian Shapiro karena dalam penelitiannya resistensi leptin dapat diinduksi oleh fruktosa pada waktu yang lebih pendek 4 minggu dengan konsentrasi yang sama (Haring SJ, 2011).

Penelitian ini ingin mengkonfirmasi berapa lama paparan fruktosa leptin dapat menginduksi resistensi leptin. Berdasarkan kajian literatur sebelumnya, masih sedikit publikasi yang menjelaskan patofisiologi resistensi leptin yang diinduksi fruktosa. Penelitian ini mencoba mengeksplorasi mekanisme resistensi leptin yang diduga disebabkan oleh penurunan ekspresi reseptor leptin tipe b utamanya di intestinum dan di hipotalamus.

\section{Desain penelitian}

Penelitian ini merupakan penelitian true experimental dengan post test only control group karena adanya intervensi perlakuan dengan menggunakan kontrol.

\section{Alat dan Bahan penelitian}

Bahan penelitian yang digunakan adalah HFCS 55\%, staining kit Skytec Laboratories Cat No AMF080-IFU an antibodi primer Bioss antibodies tipe Leptin receptor polyclonal antibody bs0109R.Alat penelitian yang digunakan adalah Mikroskop Nikon E-100 untuk pengamatan dan perhitungan jumlah ekspresi reseptor tipe $b$ leptin.

\section{Adaptasi dan terminasi hewan coba}

Sebanyak 30 tikus Rattus Novergicus (200-250 gram) diadaptasikan dalam kandang yang suhu ruangannya dipertahankan konstan yakni $22 \pm 2^{\circ} \mathrm{C}$ dengan kelembaban relatif $50 \pm 15 \%$ dan siklus gelap terang 12 jam. Seluruh tikus jantan ( 28 ekor) yang telah diaklimatisasi selama satu minggu, dibagi menjadi 4 kelompok secara acak, setiap kelompok terdiri dari 7 ekor tikus. Masing-masing tikusdiberi 
label pada ekor sesuai kelompoknya menggunakan spidol tahan air.Kelompok I adalah kontrol dimana tikus tidak diberi perlakuan fruktosa oral, intake minum adlibitum dan pakan sesuai diet standar. Kelompok II, III dan IV secara beruturutan adalah tikus yang diberi fruktosa 10, 30 dan 55\%. Fruktosa oral diberikan dengan cara disonde kepada hewan coba selama 8 minggu. Selama penelitian, mencit diperlakukan sebaik-baiknya, diusahakan agar bebas stres, leluasa bergerak dan diberikan makanan dan minuman setiap hari secara ad libitum. Pengambilan organ mencit dilakukan setelah 8 minggu untuk membandingkan apakah waktu yang lebih singkat dapat menyebabkan resistensi leptin secara bermakna. Berdarkan kajian literatur sebelumnya dari Harring SJ yang menyebutkan waktu induksi resistensi leptin seelah perlakuan dari diet tinggi fruktosa adalah 3 bulan atau 90 hari. Tikus dikorbankan dengan anaestesi urethane pada pagi hari setelah dipuasakan selama 8 jam. Tikus dibedah dan diambil preparat jaringan hipotalamus dan usus halus. Jaringan tersebut dicuci dalam dulbeccos phosphate buffered saline untuk mengeliminasi kontaminasi darah dan diawetkan menggunakan formalin $10 \%$.

\section{Pembuatan slide Imunohistokimia}

Tahapan pembuatan preparat adalah: (1) fiksasi, (2) penanaman (embedding) ; (3) pembelahan (sectioning). Setelah preparat jadi, maka dilakukan proses (1) deparafinisasi dan rehidrasi; (2) antigen retrieval. Pewarnaan preparat menggunakan prosedur sesuai yang tertera di metode staining kit yang didapat dari Scytek Laboratories Cat No AMF080-IFU. Tahapan awal dimulai dengan . meneteskan Super Block, dilakukan dengan proses pembilasan. Setelah itu preparat ditetesi menggunakan antibody primer dan inkubasi sesuai protokol manufaktur. Setelah beberapa serial pencucian, preparat diberi Ultra tek HRP dan diinkubasi selama 10 menit pada suhu kamar Langkah selanjutnya adalah menambahkan kromogen DAB ke preparat, sebagai counterstaining adalah HE. Ekspresi protein reseptor leptin tipe B terdapat pada sitoplasma sel yang ditandai dengan warna coklat dan dihitung menggunakan mikroskop serta software masing-masing 10 lapang pandang setelah itu diukur nilai rerata ekspresinya.

\section{Analisa data}

Uji statistik untuk mengetahui perbedaan ekspresi reseptor leptin tipe b antar masing-masing kelompok menggunakan uji one Way Annowa. Nilai $\alpha$ ditetapkan 0,05 dengan derajat kepercayaan 95\%.

\section{Hasil}

\section{Fruktosa tidak mempengaruhi berat badan tikus}

Tidak terdapat perbedaan yang signifikan antara berat badan sebelum dan sesudah perlakuan pada kelompok P1 dan P3, namun tidak pada P2 yang menunjukan $\mathrm{p}=0,02<0,05$. Namun dari keseluruhan grafik kami menyimpulkan bahwa pemberian fruktosa 2 bulan tidak mempengaruhi berat badan tikus pada 4 kelompok 


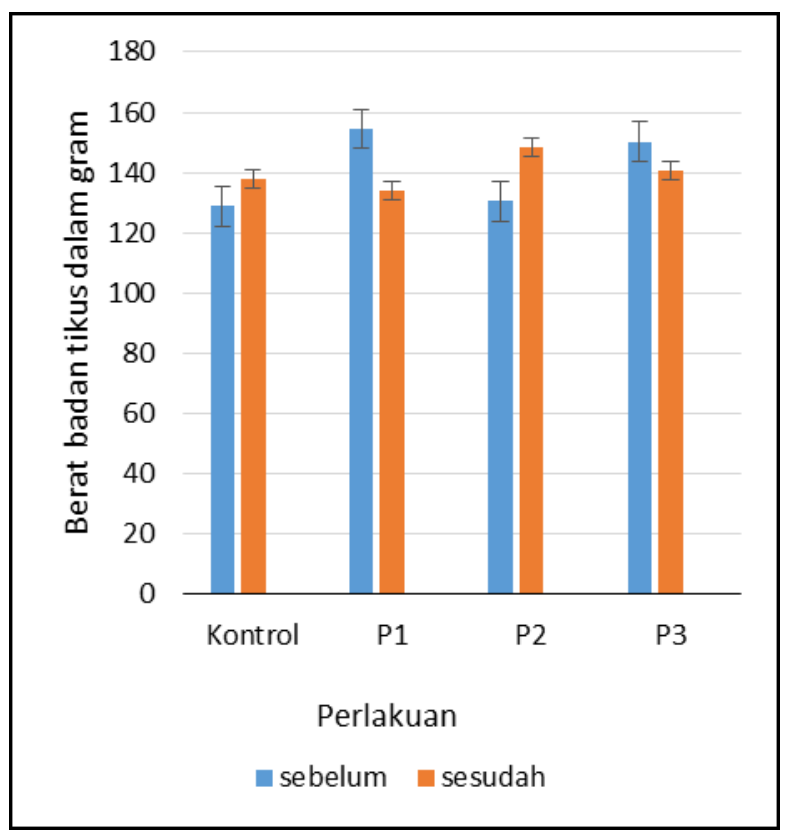

Gambar 1. Nilai rerata berat badan sebelum dan sesudah 12 minggu pada masing-masing kelompok. K=kontrol; $\mathrm{P} 1=$ perlakuan dengan fruktosa $10 \% ; \mathrm{P} 2=$ perlakuan fruktosa $30 \%$; dan $\mathrm{P} 3=$ perlakuan fruktosa $55 \%$

\section{Fruktosa menurunkan ekspresi reseptor leptin tipe b di hipotalamus dan intestinum}

Berdasar hasil uji imunohistokimia, tampak gambaran coklat di sitoplasma yang menandakan ekspresi reseptor leptin tipe $\mathrm{b}$ positif baik di hipotalamus dan intestinum.

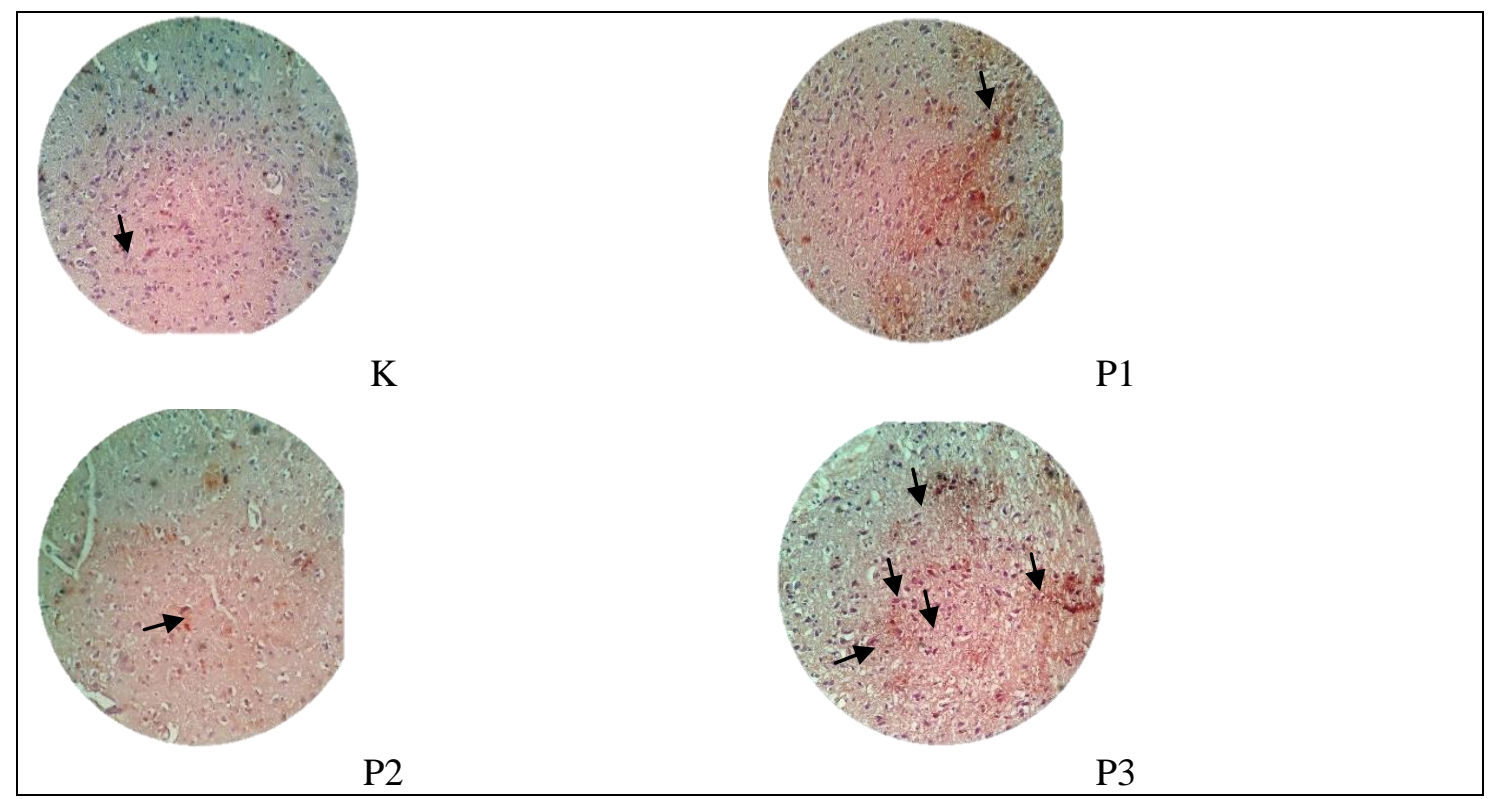

Gambar 2. Gambaran imunohistokimia ekspresi reseptor leptin tipe b di hipotalamus. Ekspresi + ditandai dengan warna coklat pada sitoplasma sel. Tanda panah adalah menunjukkan ekspresi positif reseptor leptin tipe $b$. $\mathrm{K}=$ kelompok kontrol; P1, P2 dan P3 berturut-turut=perlakuan fruktosa 10;30 dan 55\% 


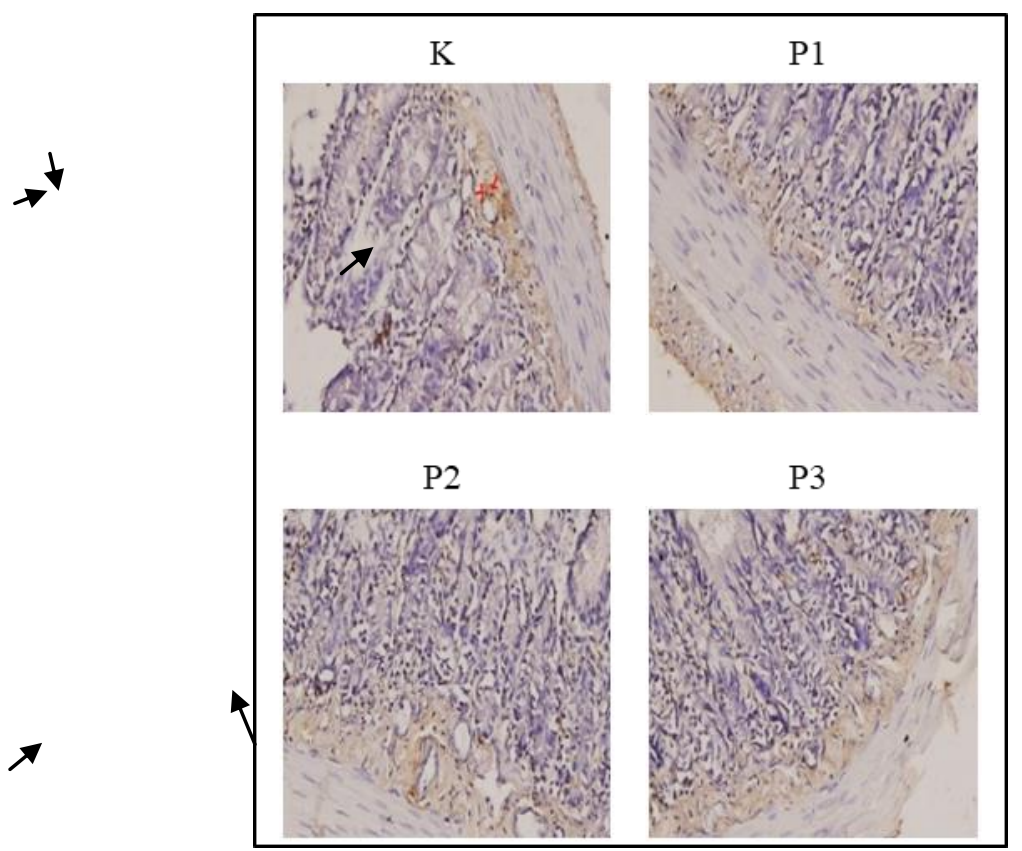

Gambar 3. Rerata jumlah ekspresi reseptor leptin tipe b di intestinum yang ditunjukkan dengan tanda panah $\mathrm{K}=$ kelompok kontrol; P1, P2 dan P3 berturut-turut=perlakuan fruktosa 10;30 dan 55\%.

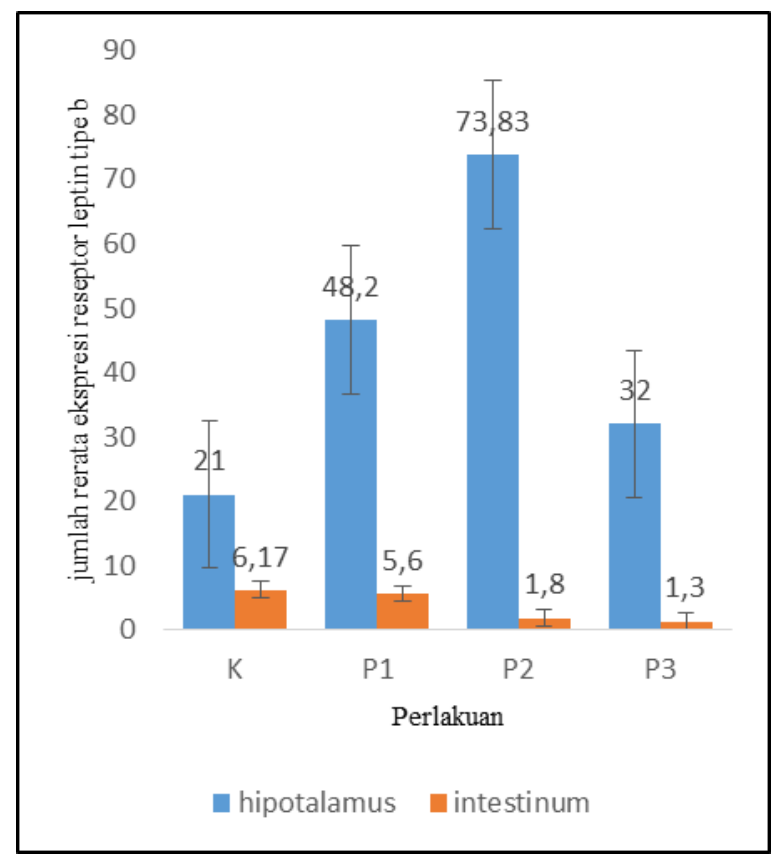

Gambar 4. Grafik yang menunjukkan nilai rerata ekspresi reseptor leptin tipe $b$ di hipotalamus dan intestinum. $\mathrm{K}=$ kontrol; $\mathrm{P} 1=$ fruktosa $10 \% ; \mathrm{P} 2=$ fruktosa $30 \%$ dan $\mathrm{P} 3=$ fruktosa $55 \%$.

Berdasar uji one way Anova didapatkan adanya perbedaan signifikan jumlah ekspresi reseptor leptin tipe b di hipotalamus antara masing-masing kelompok baik K, P1, P2, P3 ( p<0,05), dimana angkanya cenderung meningkat secara bertahap dari kelompok kontrol ke P1 diikuti dengan P2 namun trennya menurun pada kelompok P3. Sementara di intestinum, hasil uji one way Anova menunjukka adanya perbedaan signifikan antara kelompok P1 dengan P2 dan P2 dengan P3 $(\mathrm{p}<0,05)$ dengan nilai ekspresi yang menunjukkan tren menurun. 


\section{Diskusi}

Masih terdapat perdebatan mengenai kapan waktu terjadinya resistensi leptin pada paparan fruktosa konsentrasi tinggi. Penelitian Shapiro membuktikan bahwa pemberian fruktosa dosis tinggi selama 6 bulan menginduksi terjadinya resistensi leptin. Pemeriksaan Resistensi leptin oleh Shapiro diperlihatkan dengan melakukan pengamatan setelah injeksi leptin eksogenous, dimana pada kelompok fruktosa dosis tinggi tikus tidak menunjukkan pola perilaku penurunan nafsu makan. Penelitian oleh Bursac berhasil membuktikan bahwa penurunan sensitivitas leptin terjadi pada pemberian fruktosa dosis tinggi selama 8 minggu (2 bulan). Penurunan sensitivitas leptin diukur dengan ekspresi reseptor leptin menggunakan metode qPCR( Bursac, 2014). Penelitian kami melengkapi hasil penelitian Bursac bahwa pemberian fruktosa dosis tinggi selama 8 minggu menyebabkan penurunan sensitivitas insulin yang dilihat dari penurunan jumlah ekspresi reseptor leptin tipe $\mathrm{b}$ dari gambaran imunohistokimia.

Hasil penelitian ini mendukung penelitian sebelumnya bahwa fruktosa menginduksi resistensi leptin. Terdapat beberapa mekanisme yang mampu menjelaskan fenomena tersebut diantaranya adalah : defek pada produksi leptin, defek transduksi sinyal yang dimediasi leptin akibat stress reticulum endoplasma, stimulasi inflamasi kronis yang menyebabkan aktivasi jalur transduksi sinyal NFkB (Morris DL etal, 2009).

\section{Pengaruh fruktosa terhadap ekspresi reseptor leptin b di hipotalamus}

Mekanisme molekuler yang dapat menjelaskan terjadinya resistensi insulin sentral hipotalamus adalah menurunnya ekspresi gen pSTAT3 pada pemberian fruktosa dosis tinggi. Pada kondisi normal leptin menyebabkan ekspresi reseptor tipe b melalui aktivasi jalur Jak-STAT3 fosforilasi. Ketika terjadi penurunan ekspresi pSTAT3 di hipotalamus, maka tentunya hal tersebut menyebabkan kegagalan ekspresi protein reseptor leptin tipe b. Shapiro menduga bahwa penurunan ekspresi STAT3 disebabkan karena kegagalan leptin menembus Blood Brain Barrier akibat tingginya kadar trigliserida sehingga tidak mencapai titik lokasi hipotalamus. Penelitian oleh Bursac senada dengan Shapiro bahwa resistensi leptin disebabkan oleh dislipidemia yang ditandai dengan peningkatan trigliserida. Penjelasan yang sedikit berbeda diterangkan oleh Bursac bahwa peningkatan trigiliserida menyebabkan adipogenesis dan menurunnya asam lemak bebas di hipotalamus. Masih belum terdapat data mengenai mekanisme trigliserida dalam menonaktifkan ekspresi reseptor leptin tipe b di hipotalamus, apakah sesuai yang dihipotesiskan Shapiro atau bukan. Bursac melengkapi efek lanjutan dari penurunan ekspresi reseptor leptin di hipotalamus yaitu meningkatnya ekspresi reseptor NPY (neuropeptida oreksigenik) yang menyebabkan tidak adanya rasa kenyang sehingga menimbulkan perilaku makan berkepanjangan.

\section{Pengaruh Fruktosa terhadap ekspresi reseptor leptin tipe b di intestinum}

Kami memiliki dugaan kemungkinan lain mengenai penurunan sensititas leptin yaitu penurunan kemampuan absorbsi leptin di saluran cerna. Adapun dasar hipotesis ini adalah masih adanya perbedaan hasil mengenai kadar leptin plasma pada pemaparan fruktosa dosis tinggi. Pada beberapa penelitian mengemukaan bahwa fruktosa konsentrasi tinggi menyebabkan tingginya leptin plasma, sementara publikasi-publikasi lainnya menyatakan bahwa kadar leptin plasma tetap pada nilai normal.

\section{Kesimpulan}

Salah satu mekanisme resistensi leptin akibat paparan fruktosa konsentrasi tinggi secara kronis adalah adanya penurunan ekspresi reseptor leptin tipe $b$ di hipotalamus dan di intestinum. Penelitian ini hanya menggunakan satu serial waktu. Untuk pengembangan ke depannya perlu dilakukan penelitian lanjutan dengan banyak variasi waktu pengukuran dan mengeksplorasi mekanisme transduksi sinyal yang memperantarai terjadinya penurunan ekspresi reseptor leptin tipe $\mathrm{b}$ di hipotalamus dan di intestinum.

\section{Ucapan terimakasih}

Ucapan terimakasih disampaikan kepada Kementerian Agama yang sudah membiayai penelitian ini menggunakan alokasi dana BOPTN 2017. 


\section{Referensi}

Akar F, Uludag O, Aydin A, Aytekin YA, Elbeg S, Tuzcu M, Sahin K. 2012. High fructose corn syrup causes vascular dysfunction associated with metabolic disturbances in rats : Protective effect of resveratrol." Food and chemical Toxicology 50: 2135-2141.

Bezzera RMN, Ueno M, Silva MS, Tavares DQ, Carvalho CRO etal.2001.A high fructose diet induces insulin resistance but nod blood pressure changes in normotensive rats. Braz $\mathrm{J}$ Med Biol Res 34(9):1155-60

Bursac BN, Vasiljević AD, Nestorović NM, Veličković NA, Vojnović Milutinović DD etal.2014.High fructose diets leads to visceral adiposity and hypothalamic leptin resistance in male rats. J Nutr Biochem 25(4):446-55

Elliot SS, Keim NL, Stern JS, Teff K dan Havel PJ.2002.Fructose, weight gan and the insulin resistance. Am J Clin Nutr 76:911-22

French SA, Lin B, Guthrie JF. 2003. National trends in soft drink consumption among children and adolescents age 6 to 17 years : Prevalence, amounts and sources 1977/1978 to 1994/1998.J Am Diet Assoc 103:1326-1331.

Harring SJ dan Harris RBS.2011.The relation between dietary fructose, dietary fat and leptin responsiveness in rats. Physiol Behav 104(5):914-22

Malik, Popkin BM, Bray, GA, Despres J-P, Hu FB. 2010. Sugar Sweetened Beverages, Obesity, Type 2 Diabetes and. Circulation 12 (11): 1356-1364.

Martinez FJ, Rizza RA, Romero JC. 1994. High fructose feeding elicit insulin resistance, hyperinsulinemia, and hypertension in normal mongrel dogs. Hypertension 23: 456-463.

Morris DL, Cho KW, Zhou Y, Rui L. SH2B1 enhances insulin sensitivity by both stimulating the insulin receptor and inhibiting tyrosine dephosphorylation of insulin receptor substrate proteins.Diabetes. 2009; 58(9):2039-2047. [PubMed: 19542202]

Nielsen SJ and Popkin BM.2004.Changes in Beverage intake between 1977 and 2001.Am J Prev Med 27(3)205-210

Putnam JJ, Allshouse JE. 1999. Food consumption, prices, and expenditures, 1970-97. Washington, DC: Economic Research Service, US Department of Agriculture, Roglans N, Vila L, Farre M, Alegret M, Sanchez RM, Vazquez-Carrera M, Laguna C.2007. Impairment of hepatic Stat-3 activation and redux=ction of PPAR activity in male rats. Hepatology 45:778-788

Shapiro A, Mu E, Roncal C, Cheng KY, Johnson RJ, Scarpace PJ.2008.Fructose-induced leptin resistance exacerbates weight gain in response to subsequent high fat feeding

Souza AM, Pereira RA, Yokoo EM, Levy RB, Sichieri R.2013.Most consumed foods in Brazil:National Dietary Survey 2008-2009.Rev Saude Publica 47.

Walker RW, Dumke KA, Goran MI. 2014. Fructose content in popular beverages made with and without high fructose corn syrup.Nutrition 30: 928-935. 